\title{
The family doctor in the jurisprudence of medical disciplinary boards. Analysis of select cases
}

\author{
IWONA WRZEŚNIEWSKA-WALA-G
}

Department of Law, Economics and Management of the Public Health Care School of the Centre for Postgraduate Medical Education, Warsaw, Poland

A - Study Design, B - Data Collection, C - Statistical Analysis, D - Data Interpretation, E - Manuscript Preparation, F - Literature Search, $\mathbf{G}$ - Funds Collection

Summary The increase in the number of malpractice actions for damages before civil courts is linked not only to patients' increasing awareness of their rights, but also to the rapid development of medical science and new technologies, as well as the associated risk. At present, besides expert medical knowledge, a medical practitioner must have basic knowledge of the law. This article outlines, on the basis of the jurisprudence of medical disciplinary boards, the rules for medical practice that are grounded not only in the provisions of the law, but also in professional deontology. The essential rule that a practitioner may never forget at any stage of professional activity is the principle of due diligence. Examples from medical disciplinary boards cited below show that, in practice, this principle, being so fundamental to the medical profession, is violated in more than $60 \%$ of the cases at hand. These include cases involving family doctors and those practising in primary care. Medical disciplinary proceedings are brought by the disciplinary prosecutor (Rzecznik Odpowiedzialności Zawodowej), who, if convinced that professional misconduct has occurred, requests the medical disciplinary board for punishment. In regulating the disciplinary proceedings, the lawmaker provided for two instances: regional medical disciplinary board (Okręgowy Sqq Lekarski) rules in the first instance, and the Chief Medical Disciplinary Board (Naczelny Sqqd Lekarski) hears the appeals. At present, one can also challenge the latter's rulings with an appeal-in-cassation to the Supreme Court, where professional judges decide upon the case.

Key words: physicians, primary care, eligibility determination.

Wrześniewska-Wal I. The family doctor in the jurisprudence of medical disciplinary boards. Analysis of select cases. Fam Med Prim Care Rev 2018; 20(3): 291-295, doi: https://doi.org/10.5114/fmpcr.2018.78275.

\section{Background}

A medical practitioner's activities relate to such values as human life and health. Violating practice rules may lead to criminal, civil or professional (disciplinary) liability. For the purposes of professional responsibility, the practitioner is bound by two normative systems: (medical) ethics and law. The definition of professional misconduct in Article 53(1) of the Act on Medical Chambers [1] shows that every doctor, as a member of a medical chamber, has the obligation to observe medical ethical principles and comply with the legal provisions relating to medical practice, under the pain of professional responsibility. The provision on professional misconduct must be read in conjunction with Article 8(1) of the Act on Medical Chambers, which provides for the obligations of the members of the medical self-government. In accordance with this provision, members of a medical chamber have a duty to observe and comply with: 1) the rules of medical ethics; 2 ) legal provisions relating to the practice of the medical profession; 3 ) resolutions of the bodies of medical chambers. This means that on the one hand, the professional responsibility of doctors will have a narrower personal scope (being applicable solely to the members of the medical self-government), but on the other hand, broader material scope (imposing additional obligations on the members). The latter finds its rationale in the specificity of the medical profession, the nature of the tasks and the responsibility involved. The significant feature here is that the provisions on professional responsibility do not, as is the case with criminal liability, contain definitions of the various offences. The statutory concept of professional misconduct has intentionally been left vague, due to the objective impossibility of creating a list of behaviours that pose a threat to the due performance of professional obligations and to the upholding of the dignity of the medical profession [2].

One of the most important rules of professional practice for a doctor at any stage of contact with a patient is the principle of due diligence. In keeping with this principle, the practitioner should carry out all diagnostics, therapy and prevention with diligence, devoting to the patients the necessary time. Diligence, in its colloquial understanding, means conscientiousness, reliability and care for the well-being of another [3]. For a doctor, this includes the conscientious preparation of diagnosis, therapy and treatment. Conscientiousness and a sense of duty constitutes an important element in the work of any good doctor. A lack of this in the exercise of professional duties may cause, and often does cause, irretrievable harm to patients [4] and, consequently, entails legal responsibility. It is worth emphasizing that in the professional responsibility of medical practitioners, it is precisely Article 8 of the Code of Medical Ethics [5] in concurrence with Article 4 of the Act on the Professions of Physician and Dentist [6], containing the term 'due diligence', which supply the legal basis for the requests for punishment brought about by medical disciplinary prosecutors.

\section{Objectives}

The purpose of this work is to discuss select cases that were decided upon by regional medical disciplinary boards (OSL), wherein charges were pressed against family doctors and doctors practising in primary care. Particular emphasis was placed on the doctor-patient relationship in the light of legal provisions and professional ethics. The analysis of these solu- 
tions is intended to show young doctors the risks associated with the practice of medicine in POZ and, at the same time, provide useful tips for professional practice. The cases being discussed in this article illustrate the core duties of a doctor in both diagnostics and therapy. The diagnostic and therapeutic process is, in essence, a sequence of decisions leading to the resolution of the health problem of a patient requesting the doctor's assistance [7]. The gathering of information about the patient includes: 1) interview, 2) physical examination, 3) additional examinations (e.g. imaging, laboratory tests, histopathology). All these principles ought to be followed in the daily practice of family medicine or primary care. The reality, however, shows otherwise. The cases from regional disciplinary boards cited herein demonstrate that these fundamental professional principles are repeatedly violated. The typical ailments patients complain about to family and primary-care doctors include: stomach ache, symptoms of upper-limb fracture or a sudden life-threatening event with a child that have not been diagnosed in time, leading to a delay in the implementation of the correct treatment. In this connection, it becomes necessary to discuss the above violations for educational purposes, with a view towards broader inclusion of such issues in the teaching curricula for family and primary-care doctors.

\section{Material and methods}

To showcase this specificity of the medical profession, the author of this work has analysed select decisions of regional medical disciplinary boards (OSLs) for violations of legal provisions and of the Code of Medical Ethics. The author has analysed the jurisprudence of medical disciplinary boards on the basis of the case files of the OSLs in Lodz (2016), Poznan (2015-2016); Warsaw (2016) and Wroclaw, using anonymized files and decisions (years: 2012, 2013 and 2014). In this way, the author obtained a cross-section of cases from various different locations in a comparable period of time. In principle, these were closed cases and final decisions. However, due to the recent status of such OSL rulings (e.g. 2016 and 2017), they include non-final rulings (several in each OSL).

The author analysed the frequency with which the failure of due diligence was imputed to doctors. As analysed by the author, out of 55 cases before the Warsaw OSL in 2016, failure of due diligence was charged in $39(71 \%)$ cases. During the same year, out of 33 cases before the Lodz OSL, doctors faced a charge in 23 cases (69.7\%), and before the Poznan OSL, which heard 9 cases, 2 (22\%) faced charges. The year before, in the Poznan OSL, the author analysed 29 cases heard, out of which $12(41.4 \%)$ referred to Article 8 of the Code of Medical Ethics in conjunction with Article 4 of the Act on the Medical Profession. In the Wroclaw OSL, the author analysed 37 cases from 2014, with a failure of due diligence in the diagnostic and therapeutic process ruled in $23 \%(62.2 \%)$ cases; out of 35 cases analysed for 2013 , the charge provided the basis for a request for punishment in 19 (54.3\%) of the cases, and in 2012, out of 57 cases analysed, failure of due diligence was involved in 37 (64.9\%) cases. Out of all these cases selected by author for discussion the board decisions relating to family doctors and those practising in primary care.

\section{Select Cases}

\section{Upper-Limb Fracture}

A primary-care doctor was brought before the disciplinary board in Wroclaw on charges of professional misconduct in the period from January to March in the form of failure to observe due diligence in the care of a patient, whom despite her complaints of pain in the right he did not order an X-ray or refer her to a specialist in orthopaedic clinic, thus delaying correct diagnosis, i.e. dislocated right humeral head and frac- tured greater tubercle of the right humerus, in violation of Article 8 of the Code of Medical Ethics. In January, the patient fell on the pavement and suffered injury to the right upper limb. After two days, due to intensifying pain, she reported herself to the Primary Care Clinic of the Medical Diagnostic Centre, where the defendant doctor received her. The doctor interviewed the patient and obtained information about the injury. The patient also mentioned intensifying pain in and swelling of the shoulder. The doctor conducted a physical examination, in which he found a bump on the forehead and right shoulder bruising without finding any shoulder deformation. He recommended compresses for the right upper limb, pain medication and continued monitoring of the hand. Due to the recommended treatment not bringing about any expected improvement, the patient paid another visit to the defendant doctor, but the doctor once again only recommended pain medication and prescribed sedatives. With time, the pain was joined by fever, tremors and headache, resulting in yet another visit with the primary-care doctor. The defendant identified those ailments as symptoms of an infection and implemented the according treatment. The patient visited him once again in March, complaining about limb ailments preventing her ability to function normally. This was when the doctor, during a physical, found a shoulder deformation and referred the patient to the Surgical Clinic for consultation. On the same day, the patient, with a diagnosis of dislocation of the acromioclavicular joint, was sent to the Orthopaedic Department for attempted repositioning of the inveterate dislocation of the right humeral head with fractured humeral tubercle. The following day, under general anaesthesia, despite repeated attempts, it was not possible to reduce the dislocated right humeral head. Due to the good passive flexion range of the patient's shoulder, surgery for open repositioning of the dislocation was abandoned. Two weeks later, the patient was readmitted to the same health-care unit for attempted surgical treatment of inveterate dislocation of the right humeral head with fractured humeral head. Following the necessary preparation, the surgery was completed. The X-ray after the surgery found a repositioned dislocation of the right humeral head and splinters from the broken greater tubercle of the right humerus in the correct position.

Based on the evidence gathered, the OSL took the position that the patient, during the first visit, provided the defendant doctor with all information about the injury suffered and the accompanying complaints, which, together with the results of the physical examination, supplied the absolute indication for imaging diagnostics of the location of the injury and for providing the patient with specialist, i.e. orthopaedic, care in the Orthopaedic Injury Clinic. The defendant doctor failed to extend the diagnostics to an X-ray and receive specialist consultation, recommending monitoring of the limb and treatment of symptoms instead. Appropriate action was not taken with the patient when she visited the doctor for the second time, either, as clearly shows from extracts taken from the patient's files at the Primary Care Clinic. The situation was similar during the February visit, which is when systemic reactions joined in, which the defendant doctors identified exclusively as infection-related ailments. Only during the final visit, which is when the patient once again reported pain preventing her from everyday functioning, did the doctor recommend surgical consultation. In summary, the OSL took the position that the defendant doctor's conduct in respect to the assistance provided to the patient was not adequate and found the doctor guilty of professional misconduct. In the board's view, a quicker diagnosis and implementation of the correct treatment, which was therefore delayed by several months, would have prevented the patient's suffering in connection with the injury sustained and with the omission of suitable diagnostics and therapy. The severity of the penalty was mitigated by the defendant doctor's attitude during the proceedings, where he showed a significant degree of criticism toward the event, as well as contrition. The explanation he 
provided was the great number of patients he was receiving due to the prevailing flu infection at the time. He noted that he had inspected the patient's hand twice and seen nothing suspicious, and only during the later visits did the patient complain about swelling. He admitted his guilt of professional misconduct and advised that he had settled with the patient for an apology and financial compensation [8].

\section{Emergencies}

The medical board in Warsaw considered the case of a family doctor who, while on duty for after-hours assistance, did not auscultate a patient less than 3 years old. The parents brought the child because of a cough, a temperature of $39.7^{\circ} \mathrm{C}$ (the boy did not react to antipyretic medicines) and acute vomiting for several hours. They mentioned the child had shown similar symptoms recently with pneumonia. The defendant doctor, after the interview and without conducting a physical examination, recommended antipyretic medicines and micro-elements. In response to the mother's inquiry as to why he would not auscultate the child, he emphasized the boy's organism was strong, and the boy would manage even if it were pneumonia. After several hours of deteriorating condition, the mother brought the child to $A \& E$. When received, the boy was pale, with high fever and rapid breath and was vomiting. The doctor on duty at $A \& E$, after an interview, as well as physical and routine laboratory examinations, diagnosed septicaemia. It must be emphasized that such examinations could also have been conducted by the defendant doctor in after-hours assistance. At the hearing, the defendant doctor admitted to the charges and showed contrition. In his explanation, he admitted that during the holiday period, there were approximately 150 patients daily, often children, and he lacked experience with children, as his patients at the clinic tended to be older than 50 years of age. In the board's opinion, insufficient collection of data from the interview and omission of an examination due to lack of time was reprehensible [9]. Thus, the defendant's instruction as to the possibility of approaching A\&E for assistance did not justify his decision, as his own assessment of the patient's condition had not excluded the necessity of hospitalization.

\section{Stomach aches}

The regional disciplinary prosecutor charged the primary-care doctor with failure to observe due diligence with regard to her patient, resulting in the omission to order examinations to find the cause of iron deficiency and omission of a physical examination of, especially, the abdominal cavity, i.e. professional misconduct consisting in a violation of Article 4 of the Act on the Professions of Physician and Dentist and Article 8 of the Code of Medical Ethics.

The patient had been treated by a primary-care doctor for several years. Due to her complaints about weakness, dyspnoea, malaise, dizziness and swelling in the left part of the body, upon the defendant doctor's orders, the patient underwent a morphology test showing a $6.5 \mathrm{~g} / \mathrm{dL}$ haemoglobin level (with the norm being 12-16) and iron in the serum at $16 \mu \mathrm{g} / \mathrm{dl}$ (with the norm being 50-150). Based on the above results, the doctor diagnosed 'iron-deficiency anaemia', and due to the patient's low tolerance of oral medication, as was found from the interview, she decided for intramuscular iron injection, 10 injections total, every other day. Subsequently, a follow-up examination in July showed: $9 \mathrm{~g} / \mathrm{dL}$ haemoglobin and $65 \mu \mathrm{g} / \mathrm{dl}$ iron in the serum. During the visit, the patient reported feeling better. The defendant doctor included treatment with an oral iron preparation, Sorbifer Durules. A follow-up examination in September showed: $11.5 \mathrm{~g} / \mathrm{dL}$ haemoglobin and $47 \mu \mathrm{g} / \mathrm{dl}$ iron in the serum. Stomach aches started, and a different doctor referred the patient to the hospital, where an ultrasound showed, among others, free fluid in the abdominal cavity. Moreover, the patient received gynaecological consultation, which found no irregulari- ties. In December, she once again visited the defendant doctor with complaints about stomach ache and diarrhoea. The doctor examined the patient, including palpation of the abdomen, finding: soft abdomen, tenderness in the lower abdomen, no pathological resistance; Goldflam and Chełmoński symptoms were negative. The defendant doctor ordered medication with Ircolon, which is used, among others, in the treatment of symptoms of digestion disorders manifesting in a sensation of fullness, flatulence, nausea and stomach aches, as well as stress-induced disorders of the digestive system (diarrhoea, constipation, stomach ache). Several days later, the patient once again came to the Primary-Care Clinic with acute stomach aches. After a physical, a different doctor found: 'stomach ache in the right quadrant, distended abdomen, palpable tumour in the right quadrant'. The doctor decided to refer the patient to the hospital. On the same day, the patient reported to the hospital and was admitted to the General Gastroenterology and Oncology Department. The CT examination of the abdominal cavity showed ileocaecal intestinal infiltration. Due to symptoms of intestinal obstruction, the defendant went into surgery for right haemicolectomy. The histopathology showed G2 adenocarcinoma. The expert's opinion emphasized the irregularities in the defendant's conduct. She had not ordered examinations to find the causes of the anaemia. According to the expert, the defendant failed to conduct a correct physical examination, as, besides the patient's December visit, she had not performed any for a half a year.

The disciplinary board found the doctor guilty of professional misconduct and imposed a penalty. In the OSL's view, the patient's condition could only have been assessed after a personally conducted interview and physical examination. The mere finding of anaemia and recommendation of iron supplements could not be regarded as correct medical procedure. All the more so considering that the patient's tests for morphology and iron in the serum did not show clear improvement of her condition. The patient's medical files in the previous years did not contain blood-test results showing anaemia or iron deficiency. If the defendant suspected chronic anaemia in the patient, it was necessary to exclude all sources of chronic blood loss. First of all, the defendant had a duty to complete a physical, including abdomen palpation, and order diagnostics to exclude gastrointestinal haemorrhage [10].

\section{Discussion}

\section{Upper-Limb Fracture}

Diagnosis is the first and most important step in the therapeutic process. In principle, the physician commences treatment following diagnosis. The second stage that follows after diagnosis in medical procedure is treatment. The diagnostic potential of modern medicine is enormous. Diagnostic standards have been introduced in some medical fields and are of great assistance to numerous practitioners. In this connection, literature notes that a doctor who fails to conduct specialist examinations and make the correct diagnosis commits a medical error [12]. Basic diagnostics were missing from the discussed case of the family doctor who failed to order an X-ray in a patient with an injury causing intensifying pain.

\section{Emergencies}

In the practice of family doctors and primary-care doctors, diagnosis is based mainly on the knowledge of which symptoms and diseases are the most frequent. Often, frequent symptoms in patients reporting to clinics are: stomach ache, back ache, pain in the chest, headache, cough and catarrhal symptoms [13]. However, a distinction must be drawn between such obvious diagnoses and emergencies requiring a hospital referral. This is the role of the duty doctor in e.g. after-hours assistance. 
After-hours assistance provides limited diagnostic opportunities; thus, the doctor arrives at an accurate diagnosis only through a diligent interview and meticulous physical examination. Due diligence in the examination of the examination of the small child was patient was lacking in the case at hand, where the doctor only conducted an interview, but not a physical examination, and moreover did not auscultate the child, knowing him to have recently been hospitalized with pneumonia. In an unknown disease, the doctor makes the preliminary diagnosis on the basis of the interview and the physical examination. Additional examinations make it possible to select the most accurate diagnosis. Advising the parents that $A \& E$ can be of assistance if the child's condition should deteriorate does not justify the lack of diagnostics.

\section{Stomach aches}

In the physical examination, the doctor should first conduct a general examination and then detailed examination (of specific organs). In the former case, the doctor is to assess the patient's general condition, including without limitation the degree of consciousness, awareness, signs of suffering, posture, walk and physical activity. Detailed examination starts from those parts of the body that may show the largest deviation from the norm as a result of the interview and general examination. The physical examination should be by visual inspection, palpation, percussion, auscultation and measurement [14]. The examination is a relatively simply activity of great significance to the correctness of the doctor's subsequent course of action [15]. Failure to conduct a physical examination constitutes a lack of due diligence. In the OSL's view, there ought to have been a meticulous diagnosis of the patient's anaemia. Firstly, all possible sources of haemorrhage must be excluded, especially within the limits of the abdominal cavity. Apart from ordering basic laboratory tests (e.g. faecal occult blood test), the doctor has a duty to conduct a physical examination of the patient during any visit.

\section{Summary and Conclusions}

Presently, health is becoming an increasingly important and broadly discussed subject. Biological and sociological conditions of life are changing, resulting in new threats to human health [16] and new challenges for medical practitioners. In this connection, medical studies stress the importance of equipping future doctors with the necessary professional competence, i.e. the knowledge and intellectual and practical skills necessary in the profession [17]. Due diligence in medical practice is more than professionalism, however. It is beyond any doubt that medical practice, apart from suitable substantive preparation, also requires a specific ethical attitude. This attitude should manifest itself in traits and conduct of the highest moral calibre, worthy and deserving of public esteem. Here, it is necessary to consider the special role played in the functioning of the medical profession by medical disciplinary boards, which, apart from professional competence, also flesh out professional ethical principles. Władysław Biegański's observation remains relevant: 'Should anyone ask me today what virtues I found the most important to a doctor, I would reply without hesitation: humanity, conscientiousness and resolve' [18]. The author continues to investigate, for educational purposes, the rulings of medical courts. When analysing data from the District Medical Court in Warsaw for 2017, it should be noted that in comparison with the previous year, there was a slight decrease in the number of cases in which a lack of due diligence was identified. The author examined 52 cases, of which in 34 (65.4\%) physicians were charged with failure to exercise due diligence in the diagnostic and therapeutic process. There are also cases concerning family doctors and POZ doctors. However, it is too early to draw final conclusions, as some of these verdicts are not legally binding. De lege ferenda, it is necessary to recommend the inclusion of legal issues in both postgraduate and undergraduate curricula to illustrate the medical practitioner's problems and options before a disciplinary board.

Source of funding: This work was funded by the author's own resources. Conflict of interest: The author declares no conflict of interests.

\section{References}

1. Ustawa z dnia 2 grudnia 2009 r. o izbach lekarskich (Dz.U. 2009 nr 219 poz. 1708 z późn. zm.) (in Polish).

2. Wyrok Trybunału Konstytucyjnego z 27 lutego 2001 r., syng. akt K 22/00 (in Polish).

3. Muszala A, Jaranowski P. Kodeks etyki lekarskiej - odcinek 15: Z należytą starannością, poświęcając swój czas. Med Prakt 2014; 5: 114-116 (in Polish).

4. Olejnik S. Etyka lekarska. Katowice: Wydawnictwo Unia; 1995: 61 (in Polish).

5. Kodeks Etyki Lekarskiej z dnia 2 stycznia 2004 r. w brzmieniu nadanym uchwałą VII Nadzwyczajnego Krajowego Zjazdu Lekarzy z dnia 20 września 2003 r. [cited 15.08.2017]. Available from URL: http://www.nil.org.pl/_data/assets/pdf_file/ 0003/4764/Kodeks-Etyki-Lekarskiej.pdf (in Polish).

6. Ustawa z 5 grudnia 1996 r. o zawodach lekarza i lekarza dentysty (Dz.U. z 2008 r. nr 136, poz. 857 z późn. zm.) (in Polish).

7. Zaborowski P. Filozofia postępowania lekarskiego. Warszawa: Wydawnictwo Lekarskie PZWL; 1990: 127 (in Polish).

8. Orzeczenie Okręgowego Sądu Lekarskiego we Wrocławiu z dnia 9 lipca 2014 r., sygn. akt. Wu 12/14, niepublikowany (in Polish).

9. Orzeczenie Okręgowego Sądu Lekarskiego w Warszawie z dnia 19 maja 2016 r., sygn. akt OSL.630.69/2015, niepublikowany (in Polish).

10. Orzeczenie Okręgowego Sądu Lekarskiego w Łodzi z dnia 11 października 2016 r., sygn. akt 10/Wu/2016, niepublikowany (in Polish)

11. Sośniak M. Cywilna odpowiedzialność lekarza. Warszawa: Wydawnictwa Prawnicze; 1989: 79 (in Polish).

12. Liszewska A. Odpowiedzialność karna za błą w sztuce lekarskiej. Kraków: Zakamycze; 1998: 160 (in Polish).

13. Siegenthaler W. Differential diagnosis in internal medicine. In: Zaborowski P. ed. Rozpoznanie różnicowe w medycynie wewnętrznej. Od objawu do rozpoznania. Warszawa: Medipage; 2009: 11 (in Polish).

14. Bolechowski F. Podstawy ogólnej diagnostyki klinicznej. Podręcznik dla studentów medycyny. Warszawa: Wydawnictwo Lekarskie PZWL; 1985: 146-147 (in Polish).

15. Kędziora R. Odpowiedzialność karna lekarza w zwiq̨zku z wykonywaniem czynności medycznych. Warszawa: Wolters Kluwer; 2009: 210 (in Polish).

16. Rużyło E. Etyka i medycyna. Warszawa: Oficyna Wydawnicza „Stopka”; 1999: 141-150 (in Polish).

17. Obara M. Kształtowanie postaw prospołecznych podczas studiów lekarskich. In: Imieliński K, ed. Medycyna u progu XXI wieku. Godność chorego człowieka. Warszawa: Polska Akademia Medycyny; 1996: 186 (in Polish).

18. Biegański W. Myśli i aforyzmy o etyce lekarskiej. Konin: Wydawnictwo „Przegląd Koniński”; 1997: 58 (in Polish). 
Tables: 0

Figures: 0

References: 18

Received: 15.05.2018

Reviewed: 25.05.2018

Accepted: 09.06.2018

Address for correspondence:

Iwona Wrześniewska-Wal, MD, PhD

Szkoła Zdrowia Publicznego CMKP

ul. Kleczewska 61/63

01-826 Warszawa

Tel.: +48 22 560-11-41

E-mail: iwona.wrzesniewska-wal@cmkp.edu.pl;

idrwal@yahoo.com 